\title{
Study on Properties of Jute Fiber High Strength Concrete
}

\begin{abstract}
Asrar UI Haq
Abstract: In this study deals with the concept of fiber reinforced concrete using jute fiber concrete made of cement is strong in compession but weak in tension and this concrete has little resistance to cracking which limits its use. These restruction can be overcome by blending the concrete with fiberous materials which we called as fiber reinforced concrete. This study includes the strength charcteristice of mechanical properties like compression strength, split tensile strength. Tests result shows that the concrete mix with jute fiber can be used in pavement as reinforcing materials.
\end{abstract}

Keywords: Tensile strength, compressive strength, flexural strength, sustainable development, jute fiber

\section{Introduction}

As we know that the sustainable development with higher strength have growing demand of construction industry. Jute fiber is one of the cheapest natural fibers and it can be obtained at very low price and it doesnot require modern and high quality technology. We can easily by this and it have very high demand because of its low cost, low density and abundance.

To increase the structural strength, it contain fibers material in forced concrete. This concrete has drawbacks that concrete it is brittle, haspoor resistance to crack opening, poor tensile strength. Jute fiber are used for making rope, jute carpets, gunny bags and various furnishing materials like shopping bags, sail cloth etc.

\section{Methods}

1) The jute fibers were soaked in a $6 \% \mathrm{NAOH}$ solution.

2) The fibers were kept immersed in the alkali solution for 2, 3, 4, $7 \& 8 \mathrm{hrs}$.

3) The fibers have to wash several times with fresh water to remove any sodium hydroxide sticking to the fiber surface.

4) Then the fiber were dried at room temp for hours followed by oven drying at $100^{\circ} \mathrm{C}$ for three hours.

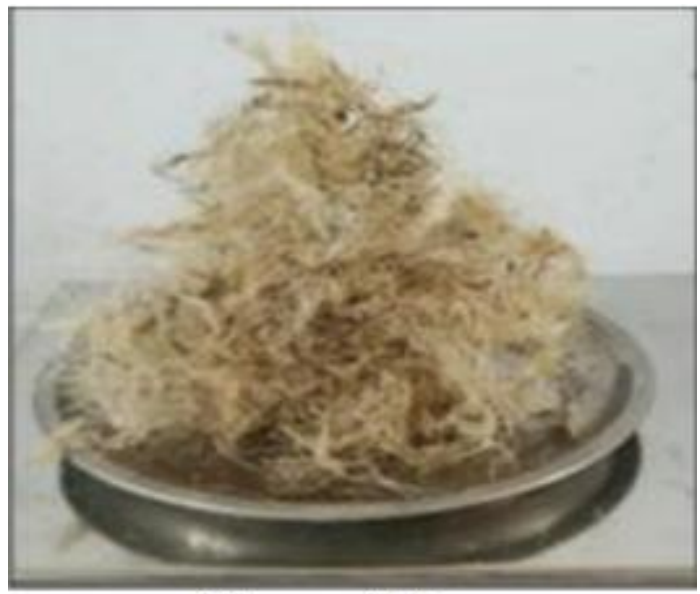

Chopped fibers

\section{Compressive Strength Test}

Concrete is a mixture of sand cement and aggregate the concrete strength depends on the individuals compressive of its components, the quality of the materials used, water cement ratio, the ratio of air mixture and many other factors. By conducting this test, one can easily determine the strength psi of the concrete being produced. The compressive strength of concrete range from 15 MPA (2200psi) to 30 MPA (4400psi) for residential concrete and is high in commercial structure. Compressive strength of concrete $=$ Maximum compressive load carried by specimen/ cross sectional area surface of specimen.

\section{Split Tensile Test}

Split tensile strength of concrete is conducted as per IS: 5816- 1999 for testing the concrete cylinder specimens with different concrete of jute fibers for different curing periods such as $7,28,56,90$, days. It is observed that at the initial stage i.e. 7 and 28 days the compressive strength of jute fiber reinforced concrete declines with increase in jute content with respect to ordinary concrete. But on furthers curing i.e for 56 days, the compressive strength of jute fiber reinforced concrete increase up to $1 \%$ jute content and on further curing the compressive strength of jute fiber reinforced concrete decreases. 


\section{Flexural Strength}

Flexural strength of concrete is conducted as per IS: 5161959 for testing the concrete prism specimens with different contents of jute fibers for different curing periods such as 7 , 28, 56, 90, days
The flexural strength of concrete reinforced with jute fibers increases with jute contents up to $1 \%$ and increase in strength continues up to 56 days of curing. On further curing, the flexural strength of JFRC decline with respect to concrete.

\section{Results and Dicussion}

Table 1.1: Observation table for compressive strength of concrete cube specimens

\begin{tabular}{|c|c|c|c|c|c|}
\hline Quantity & $\begin{array}{c}\text { Cube } \\
\text { ID }\end{array}$ & $\begin{array}{c}\text { Load } \\
(\mathrm{KN})\end{array}$ & $\begin{array}{c}\text { Area } \\
(\mathrm{cm}) \cdot 2\end{array}$ & $\begin{array}{c}\text { Comp. strength } \\
(\text { (P/A) }\end{array}$ & Days \\
\hline $0 \%$ & A & 1500 & 225 & 7.666 & 7 \\
\hline $1 \%$ & B & 1590 & 225 & 7.066 & 7 \\
\hline $2 \%$ & C & 1655 & 225 & 7.465 & 7 \\
\hline $3 \%$ & D & 1680 & 225 & 10.533 & 7 \\
\hline $0 \%$ & A & 2370 & 225 & 10.662 & 28 \\
\hline $1 \%$ & B & 2390 & 225 & 10.711 & 28 \\
\hline $2 \%$ & C & 2410 & 225 & & 28 \\
\hline
\end{tabular}

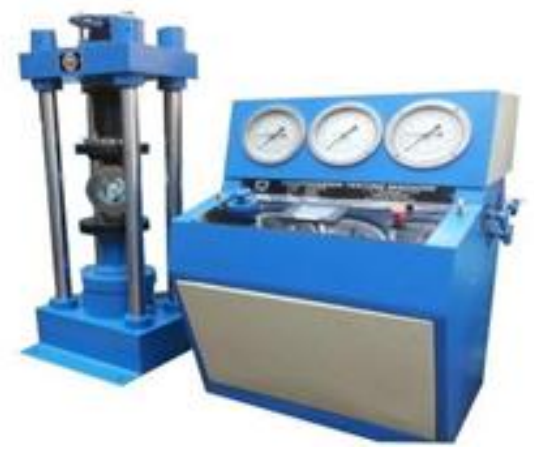

\section{Compression Test on Cube}
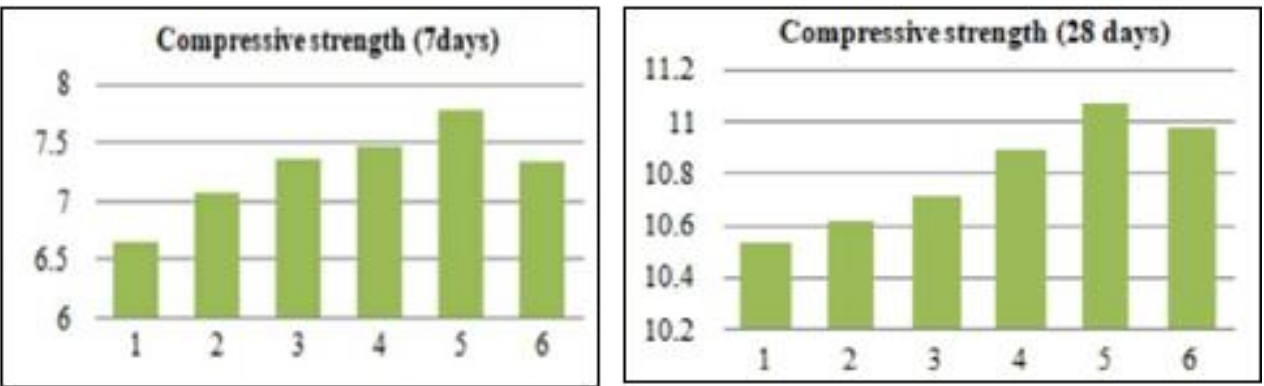

Table 1.2: Observation table for split tensile strength of cube specimens

\begin{tabular}{|c|c|c|c|c|c|c|}
\hline Quantity & $\begin{array}{c}\text { Cube } \\
\text { ID }\end{array}$ & $\begin{array}{c}\text { Crushing } \\
\text { load (KN) }\end{array}$ & $\begin{array}{c}\text { Length } \\
(\mathrm{cm})\end{array}$ & $\begin{array}{c}\text { Depth } \\
(\mathrm{cm})\end{array}$ & $2 \mathrm{p} / \pi \mathrm{ld}$ & Days \\
\hline $0 \%$ & A & 29.00 & 15 & 15 & 0.082 & 7 \\
\hline $1 \%$ & $\mathrm{~B}$ & 32.00 & 15 & 15 & 0.090 & 7 \\
\hline $2 \%$ & $\mathrm{C}$ & 37.00 & 15 & 15 & 0.104 & 7 \\
\hline $3 \%$ & $\mathrm{D}$ & 40.00 & 15 & 15 & 0.113 & 7 \\
\hline $0 \%$ & $\mathrm{~A}$ & 31.00 & 15 & 15 & 0.087 & 28 \\
\hline $1 \%$ & $\mathrm{~B}$ & 36.00 & 15 & 15 & 0.101 & 28 \\
\hline $2 \%$ & $\mathrm{C}$ & 42.00 & 15 & 15 & 0.008. & 28 \\
\hline
\end{tabular}
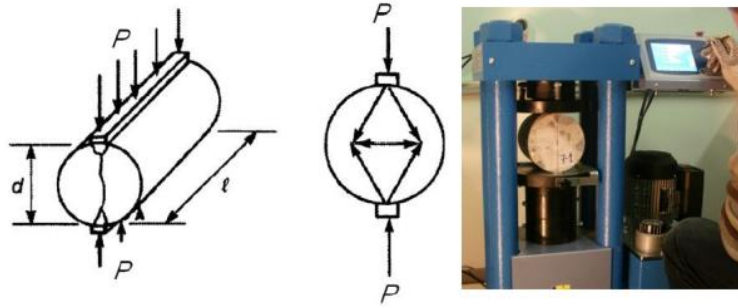


\section{Split Tensile Test}
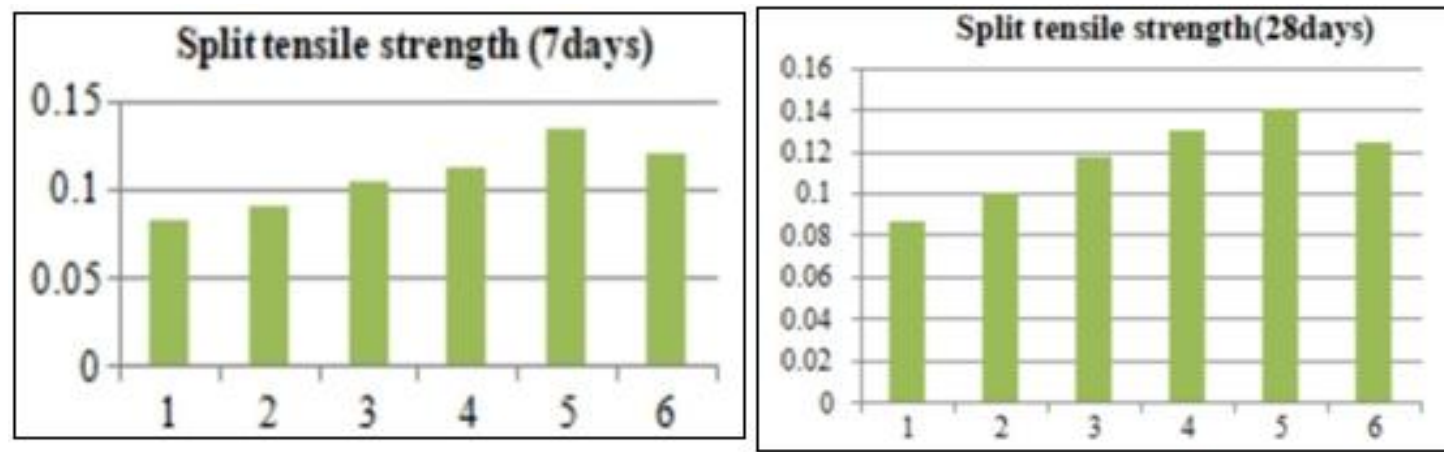

Table 1.3: Observation table for flexural strength of beam specimens

\begin{tabular}{|c|c|c|c|c|c|c|c|}
\hline Quantity & $\begin{array}{c}\text { Cube } \\
\text { ID }\end{array}$ & $\begin{array}{c}\text { Load } \\
(\mathrm{P}) \mathrm{KN}\end{array}$ & $\begin{array}{c}\text { Leff. } \\
(\mathrm{cm})\end{array}$ & $\begin{array}{c}\mathrm{D} \\
(\mathrm{cm})\end{array}$ & $\begin{array}{c}\mathrm{B} \\
(\mathrm{cm})\end{array}$ & $\begin{array}{c}\text { PLeff/2 } \\
\text { bd'2 }\end{array}$ & Days \\
\hline $0 \%$ & $\mathrm{~A}$ & 35 & 65 & 15 & 15 & 0.674 & 7 \\
\hline $1 \%$ & $\mathrm{~B}$ & 35 & 65 & 15 & 15 & 0.674 & 7 \\
\hline $2 \%$ & $\mathrm{C}$ & 35 & 65 & 15 & 15 & 0.712 & 7 \\
\hline $3 \%$ & $\mathrm{D}$ & 37 & 65 & 15 & 15 & 0.770 & 7 \\
\hline $0 \%$ & $\mathrm{~A}$ & 70 & 65 & 15 & 15 & 1.348 & 28 \\
\hline $1 \%$ & $\mathrm{~B}$ & 73 & 65 & 15 & 15 & 1.405 & 28 \\
\hline $2 \%$ & $\mathrm{C}$ & 77 & 65 & 15 & 15 & 1.482. & 28 \\
\hline
\end{tabular}

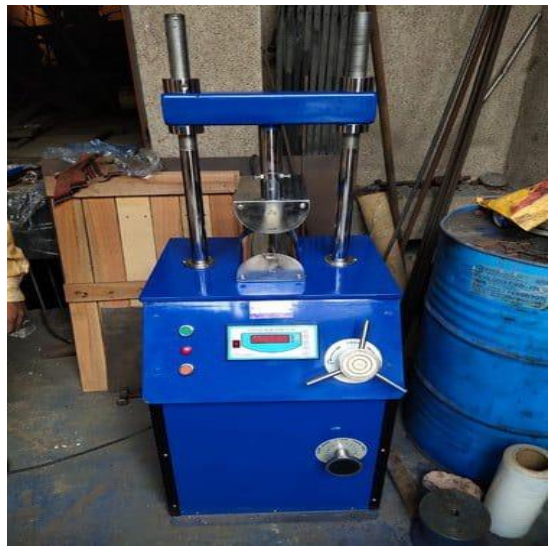

\section{Flexural Test on UTM}

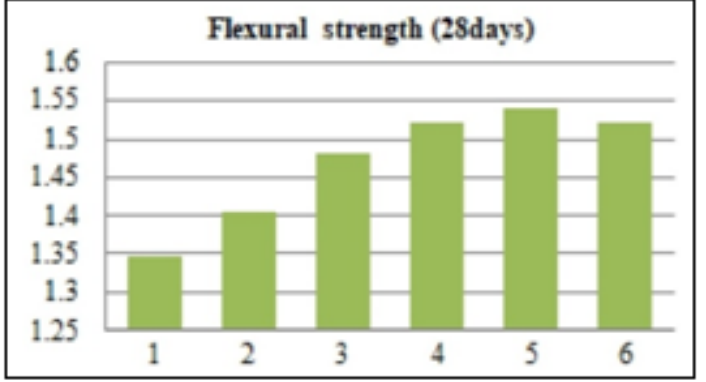

\section{Conclusion}

The result obtained by this research work indicates that jute fibers reinforced concrete have best mechanical properties. By this means it is concluded that by adding jute fibers, the compressive strength, tensile strength \&flexural strength increase to $33 \% 10 \% \& 12 \%$ respectively.

When concrete mix with jute fibers improved the compressive, tensile \& flexural strength as well as higher resistance value. This research study aims to evaluate the effect of jute fiber ( chopped) on the compressive strength and tensile strength of the concrete after 7 days and 28 days

\section{References}

[1] M.F Omar, A.A.M. Mazuki, S. Safiee. Z. A. M. Ishak, A. Abu Bakar Kenaf, fiber reinforcerd composites: A Review. Material and Design 2011: 32: 4107-4121.

[2] Sandeep Panchal Dr. Shasi Kant Sharma, Mohd Mohsin Khan, Anurag Sharma and Dr. Amrit Kumar Roy. Effect of glass reinforcement and glass powder on the

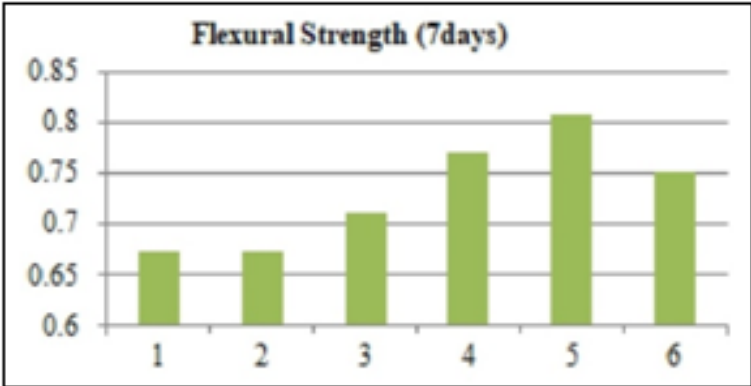

characteristic of concrete, International journal of Civil Engineering and Technology, 8 (3), 2017, pp, 637-647.

[3] Bhavesh Joshi, Dr. R.P Arora. (2015, November).PAVEMENT DESIGN BY USING GEOTEXTILE. International journal of civil and technology (IJCIET), 6 (11)6.

[4] Saandeepani Vajje, Dr. N.R. Krishnamurti, "study an addition of natural fiber into concrete', International journal scientific and technology, volume: 02, issue: 11 November- 2013 The physical and

[5] Mechanical characteristic of cement mortar', Elsevier, volume: 49, issue: Dec2013

[6] I: S 5816-1999: Method of test splitting tensile strength of concrete [CED2: Cement and concrete]

[7] I: S 516-1959: Method of tests for strength of concrete [CED2: Cement and concrete] 